\title{
Age related factors and $L 2$ learning. Implications for selecting an appropriate L2 programme
}

\begin{abstract}
This paper has been inspired by Dimroth and Stephany's longitudinal study (Dimroth, 2008) on the acquisition of German by two Russian girls, members of different age groups (8 and 14). Both girls were subjected to the same type of second language program called 'submersion and withdrawal', but showed different progress. Whilst the 8-year old became fluent in German, the 14-year old had difficulty expressing herself in her second language. This paper considers various theoretical approaches and research findings in order to account for the differences between the two learners. By all accounts there may be no single factor responsible for their individual success rates.
\end{abstract}

Key words: 'submersion and withdrawal', L2, language acquisition, language learners.

\section{Introduction}

In a study by Dimroth and Stephany (Dimroth, 2008) the acquisition of German by two Russian girls (sisters) age 8 and 14, was analyzed. The two girls arrived simultaneously in Germany with their parents and started to learn German in a nonguided way. Both girls attended the same school which had a policy of 'submersion and withdrawal' for the acquisition of German as an L2. Four years later, the parents moved to Vienna. At this point, the older child decided to move back to Russia, the younger stayed with her parents in Vienna, but would have liked to return to her friends in Germany. The results show that the younger child speaks German fluently, while the older has many problems expressing herself in German. This paper discusses the possible reasons for the different success rates of the two girls.

\section{Monolingual system}

When thinking about the different success rates of the two L2 learner one of the possible reasons that comes to mind is the nature of the L2 system they were exposed to. First of all, the system of 'submersion and withdrawal' is a type of monolingual education for language minorities. There is a generally accepted view nowadays that bilingual language learning has an advantage over the monolingual one, having in mind that monolingual education can result in certain negative side effects such

1 cmarijana_2000@yahoo.com 
as loss of minority language and sometimes language death of minority groups.

A case study by Saville-Troike (1982) illustrates how a monolingual policy frequently supports language maintenance and goes against assimilation, while a bilingual policy greatly supports assimilation of L2 speakers into the prevailing language group. Saville-Troike (1982) gives an example of two Pakistani groups: Pashto and Baluchi who share a common culture, but speak two different languages and have different attitudes to social organization. The policy of the first tribe was that they required Pashto for full political participation, which means that monolingualism was supported, while the structure of Baluchi tribes allowed bilingual participation and more easily assimilated nonBalluchi speakers. The two different policies finally contributed to the spread of Baluchi at the expense of the Pashto in the region.

\section{The nature of 'submersion and withdrawal' L2 classes}

According to Garcia (1997: 411) 'submersion and withdrawal' is a kind of L2 program which is easiest to plan, and therefore is widespread. Language minority students attend mainstream classes where no provisions are made for them. Thus, they are submersed in the majority language for all content, but they are 'withdrawn' or 'pulled out' for second language instruction with a language teacher. As soon as students become bilingual, the L2 instruction ceases.
This program is characterized by a fast conversion to the majority language and this according to Baker (1993: 199) 'stands chance of doing more harm than good'.

\section{Implications for the Russian girls' case}

Taking into account the general characteristics of 'submersion and withdrawal' program, it may be expected that the final outcome with both of the L2 learners would be fast transition to German, and possibly final loss of their L1. However, while the system worked in the case of the younger girl, but not in the case of the older one, it is obvious that their different performances in their L2 German are not caused exclusively by the type of the system applied. Instead, other factors as well as possible interaction between several factors may have caused the differences in the two L2 learners.

\section{Age factor}

Different performances of the two girls may be age related, having in mind that the younger girl is eight years old, while the older one is fourteen. According to Eckert (1997) the two girls fall within two different age cohorts, the first being in the period of childhood, the second one falling within the scope of adolescence. These two age groups show different properties. Children are more socioeconomically mobile: adults are not their primary linguistic models, but interaction with siblings, neighbours and friends influences them very much. Adolescents, on the other hand are less socioeconomically mobile and they feel that they belong to a separate age cohort. This is another possible reason why the younger learner was more successful than the older one.

Table 1: Baker (1993: 153) illustrates the 'submersion and withdrawal' L2 programme by the following table:

\begin{tabular}{|c|c|c|c|c|}
\hline Type of program & Type of child & $\begin{array}{c}\text { Language of the } \\
\text { classroom }\end{array}$ & Educational aim & Linguistic aim \\
\hline $\begin{array}{c}\text { Submersion and } \\
\text { withdrawal }\end{array}$ & Language minority & Majority & Assimilation & Monolingualism \\
\hline
\end{tabular}




\section{Identity as a factor in language learning}

There is an increasing feeling of identity inherent to the period of adolescence, and since identity and language according to Fishman (1997: 329) always go together, it is reasonable that feeling of belonging to a certain group means also sharing the language of the group. What follows from this is that the fourteen-year old girl may have had more pronounced feelings of identity and may have seen herself as belonging to the Russian ethnic group and moreover to the exclusively Russian speaking group. If we also have in mind that the basic aims of the system 'submersion and withdrawal' are assimilation and monolingualism, then the causes of failure of the 14-year-old girl are more evident. She may have seen the system as a kind of suppression of her identity and therefore, she might have been liable to conflict with native speakers, who are at the same time members of a different culture.

L2 acquisition was quite different for the younger girl who being in the period of childhood, and not having yet developed a strong feeling of belongingness to a certain group may not have seen the above described system of schooling as a kind of suppression and therefore was more willing to learn her L2.

\section{Lerner-specific characteristics}

Of course, we must not exclude the fact that a bilingual situation is always specific. According to Tabouret-Keller (1997:320) a bilingual speaker may gain different feelings from a contact of two languages: sometimes this contact gives rise to feelings of inferiority, discrimination or exclusion from the dominant group or conversely feelings of familiarity and recognition amongst those who share the contact situation. Even the initial attitudes and expectations about a new language and new culture may be different: some people reject their own group and wish to change and belong to some other group, while others value their own group membership and do not wish to acculturate. On some other occasions, however, people wish to be members of more than one group and be bicultural as well as bilingual. Saville-Troike (1982:198) reports problems of bilingual parents in the USA (who speak other languages at home) once their children begin school. Some children want to speak only English at home and they also force their parents to do so. On the other hand, some children attending bilingual school programmes willingly speak both of their languages.

\section{Critical Period}

Another possible reason, which is more linguistically grounded and which is also connected to the learner's age is the so called notion of Critical Period, which can as well be responsible for different L2 outcomes in the two girls.

Biologist Lenneberg (1967) formulated his $\mathrm{CPH}$ (Critical Period Hypothesis) in respect to second/foreign language learning. According to him, the possibility of reaching native-like levels in L2 is age restricted. Critical period appears, according to Lenneberg round puberty, which is around the age of 12 or 13 , and is caused by biological factors. The brain loses the ability of adaptation, the so-called neural plasticity, because language functions are supposed to be established by this age. After this, age related 'window of opportunity' is closed, automatic learning of a second language by a mere exposure to it seems to disappear and from that point on foreign languages have to be taught and learned through a conscious and laboured effort.

If Lenneberg's hypothesis is true, it well explains the difference in the progress of the two girls. According to these criteria 'the window of opportunity' has already closed in case of the older girl, and that is why her performance in German is inferior when compared to her sister, and it is less likely that she would reach a native-like fluency. On the other hand, the younger girl is well before the Criti- 
cal Period (according to Lenneberg at least), which explains her success in acquiring her L2 German. However, some other theorists (Pinker, 1994 etc.) place the boundaries of CP around the age of six. According to this hypothesis, the younger girl had too reached the $\mathrm{CP}$ when she began learning her L2, which then does not offer any explanations for the differences between the two sisters. However, if we take a middle solution proposed by Birdsong and Molis (1998[reported in Hyltenstam \& Abrahamson, 2000]) who suggest the age effects over the whole life span, i.e. the younger one starts learning L2, the better the outcomes, this can still account for the differences in the L2 performance between the two girls.

\section{Conclusion}

This paper seeks to account for the different learning outcomes of the two learners belonging to two different age groups (age 8 and 14) and being exposed to the same 'submersion and withdrawal' learning system. The first thing to be noted is that there is not a single factor which can account for the difference in the success rates of the two girls. One cannot criticize the system of 'submer- sion and withdrawal' and blame it for the failure of the older learner because it was obviously successful in the case of the younger learner. It could be suggested that this system may work only for younger L2 learners, while some other system may be bettersuited for the older ones. From the above data it also follows that the period of adolescence plays a special role in the formation of both learners. Obviously, it is in this period that individual's identity and feeling of belonging to a certain group is created, so this period of learner's life may be responsible for his/her attitude towards acquiring an L2. Although we cannot make any strong statements about the role of the Critical Period, having in mind that this is still an unresolved issue, there is still the fact that the rate of L2 learning was higher for the younger learner and this may imply that age effects increase over the life span. It follows that age is a very important factor in language learning and in order to produce the best results possible, the language learning system has to be designed as to suit the age of the learner. The older the learner, the more effort should be invested into L2 teaching techniques. Finally, one should not forget that bilingual situation is always specific and that there are individual learner characteristics that should be taken into account.

\section{References}

- Baker, C. (1993). Foundations of Bilingual Education and Bilingualism. Philadelphia: Multilingual Maters Ltd.

- Dimroth, C. (2008). Age Effects on the Process of L2 Acquisition? Evidence From the Acquisition of Negation and Finiteness in L2 German. Language learning, 58(1): 117-150.

- Garcia, O. (1997). Bilingual Education. In: Coulmas, F. (ed.). Handbook of Sociolinguistics (405-420). Oxford \& Cambridge (Massachusetts): Black well Publishers Ltd.

- Eckert, P. (1997). Age as a Sociolinguistic Factor. In: Coulmas, F. (ed.). Handbook of Sociolinguistics(151-167). Oxford \& Cambridge (Massachusetts): Black well Publishers Ltd.

- Hyltenstam, K and Abrahamson, N. (2000). Who can become native-like in a second languge? All, some, or none? Studia Linguistica, 54(2), 150-166

- Saville-Troike, M. (1982). The ethnography of communication. New York: Holt, Rinehart \& Winston.

- Tabouret-Keller, A. (1997). Language and Identity. In: Coulmas, F. (ed.). Handbook of Sociolinguistics(315-326). Oxford \& Cambridge (Massachusetts): Black well Publishers Ltd. 


\section{др Маријана П. Церовић}

Универзитет Црне Горе, Филозофски Факултет, Никшић

\section{Фактори узраста и учење страног језика - поуке при бирању одговарајућег програма страног језика}

Овај рад је инспирисан лонгитудиналном студијом К. Димрот и С. Хаберцетл (Димрот, 2008) о усвајању немачког језика од стране две младе Рускиње, које су припадале различитим старосним групама (осам и четрнаест година). Обе девојчице су биле изложене истом програму учења страног језика „Submersion and Withdrawal“, али су показивале различит напредак. Док је осмогодишњакиња постала флуентна у немачком, четрнаестогодишњакиња је имала потешкоћа да се изрази на страном језику. У овом раду се разматрају различити теоријски приступи и резултати истраживања ради објашњења разлика између два ученика. По свему судећи, не постоји само један фактор који је одговоран за индивидуално постигнуће ученица.

Клучне речи: „Submersion and Withdrawal“, страни језик, усвајање језика, ученици страног језика. 